mixed in a stout test tube and confined by a greased cork. This was placed upright on a little wooden stand, and kept in its place by a brass clip. About an inch of magnesium ribbon was suspended in a small tin shade by means of a wire clip. The magnesium being placed near the tube and lighted, the gases united with a report, jerking the cork to the ceiling, but in no case breaking the tube.

IV.

\section{A NEW BUBALE, FROM ABYSSINIA}

THE British Museum has just received a series of skins of a new Bubale from Abyssinia called Tora. It is like the Hartibeest for having a white patch on the rump, and white inside the ears, but it is without any black on the face or on the outer side of the limbs. It is of a bright pale bay colour, with black tuft on the tail, and the horns are much more slender than in the Hartibeest. propose to call it Alcephalus tora.

\section{J. E. GREY}

\section{FROII ANERICA TO ENGLAND BY BALLOON}

$T$ HERE appears every likelihood that before the end 1 of the year a feat will be attempted which seems to have been first seriously proposed thirty years ago by Prof. Wise, an American aëronaut, who is now making preparations to cross the Atlantic to England in a monster balloon. The American correspondent of the Standard has given full details of the elaborate construction of this balloon, and states the reasons which inspire Prof. Vise with unhesitating confidence that he will be able successfully to accomplish his aërial voyage.

The balloon, when completed, will be $160 \mathrm{ft}$. high, and the globe will be over rooft. in diameter. It will be able to lift from the ground, including its own weight, $14, \infty 00$ pounds, and will have a net carrying capacity for passengers and ballast of 6,900 pounds. It will contain 600,000 cubic feet of illuminating gas, though only 400,000 fect will be put into it to allow for expansion in the higher regions of the atmosphere. The other details of construction are most elaborate, and every precaution seems to be taken to insure success and to provide for the safety of the four persons who are bold enough to risk their lives to gratify their curiosity and endeavour to increase the sum of human knowledge. The four voyagers will be Prof. Wise, Mr. Donaldson, an agent of the Daily Graplici, and a skilled mariner-for a copper-fastened cedar lifeboat, $22 \mathrm{ft}$. long and $4 \frac{1}{2} \mathrm{ft}$. beam, forms part of the appurtenances.

The hypothesis on which the enterprise is projected, is that there is a prevailing east-going current of air at an attainable elevation, in which a balloon can pass eastward from the American continent to Europe. The current is believed to be half-a-mile or more above the surface of the earth, and to move at the rate of from 50 to 150 miles an hour. It was a knowledge of this current that made Mr. Charles Green, the celebrated English aëronaut, say, in 1840, that he should start from America rather than from England to traverse the Atlantic in a balloon. The cause of the current is less definitely known than the fact. A French savant attributes it to "a decrease of participation in the rapidity of the rotary motion of the earth." Prof. Wise believes that this upper current of air, in the temperate zones, moves from west to east, because of the mingling of the south-west and north-west trade-winds in their circuits, in accordance with the laws of temperature and the aërial motion of the earth. The two currents, he believes, slide over each other, and the balloonist who knows his business can strike such a point as will carry him eastward, as it were, between them. That is to say, the zone lying between the 35 th and 36 th parallels is "a nodal zone," in which the south-west and north-west winds induce an intermediate current which moves nearly due east. In this highway the motion is about a hundred miles an hour.

The theory of the east-going current seems to be pretty well admitted. The direct experience which bears most strongly upon it is limited. There are three memorable balloon trips which are noteworthy. The current scems to set persistently eastward, deflected slightly towards the north by the rush of equatorial air towards the north. Prof. Wise, in 1859 , in his trip from St. Louis to Jefferson county, in the State of New York, found the current almost due east; he travelled in balloon 1,156 miles in I9 hours. The speed here was only $6 r$ miles an hour; but this can be accounted for. The great balloon voyage made by Nadar from Paris to Hanover was almost due eastward. This journey of 600 miles was made in about six hours-about a hundred miles an hour, although it was over the uneven surface of the Continent, diversified by hill, vale, stream, and so on. In the trip of Mr. Green, from London to Wellburg, in Nassau, the journey was about 600 miles, and was performed at the rate of about $\mathrm{a}$ hundred miles an hour, and there were the British Channel and other irregularities in the way of smooth sailing.

On the other hand, however, Mr. Glaisher in his experiments, in consequence of what Mr. Green had stated with regard to the constant prevalence of a current from the west, paid special attention to this point, and in his reports to the British Association in 1863 and 1864 , * collected together the different directions in which the balloon had moved at different heights in his several ascents. From these it appears that the direction of the wind was quite as capricious at heights exceeding $5,000 \mathrm{ft}$. as it is on the surface of the earth. In Mr. Glaisher's winter ascents he did generally meet with a current from the south-west, certainly ; but the number of such ascents was not great, and they were not to sufficient elevations to afford very trustworthy results. It is certain, however, that if there existed over England anything like a current of air constant in direction, it must have manifested itself distinctly in the course of Mr. Glaisher's thirty ascents, in all of which the direction of the wind at different eleva. tions was a subject of careful observation.

Again, Prof. Newton of Yale College has written a letter to a recent number of the Daily Graphic, in which, from the observed behaviour of the luminous trains sometimes left by the brighter meteors at from forty to seventy miles high, he draws certain inferences which do not seem altogether favourable to Prof. WVise's theories. What these inferences are will be seen from the conclusion of his letter :-

"We have, then, at the bottom of the atmosphere, inconstant winds. TVe have just above us strata of air moving in diverse directions, for the lower clouds may move one way, the upper clouds another, while at the surface the winds may perhaps blow in a third. At two islands at short distances from each other we often have different winds.

"Again, we have for air near the top of the atmosphere, at least so high up that the density is exceedingly small, this fact, that lines (usually inclined to the horizon) only five or ten miles long almost always have their ends in air that is moving in different directions.

"Between the highest cloud and the lowest meteor trains lies an unknown region. It may be that here are uniform westerly winds. In the absence of direct observation neither this nor the contrary may be asserted. But it seems to me more rational to suppose that the complex system of currents at the bottom of the atmosphere is in direct connection with that at the top, and that there is a like complex system of currents and winds throughout the intermediate space. Of course, the general drifting of the air in the temperate zone to the east is unquestioned.

Prof. Joseph Henry, of the Smithsonian Institution,

* British Association Reports, $2 \& 63$, p. $5 \circ 7$ and $186_{4}$, p. $3^{13}$. 
who has had thirty years of observation in this direction, says :-

"All the observations that have been made in the motions of the atmosphere, as well as the deductions from theoretical considerations, lead to the conclusion that the resultant motion of the air around the whole earth, within the temperate zones, especially about the middle of them, is from west to east.' Prof. Watson, the distinguished astronomer of the Michigan University, writes, 'I beg to say that there ought to be a strong current of air moving eastward in the upper regions, and that the experience of aëronauts goes to show that what the theory predicts actually exists. It seems to me quite possible to make an aërial voyage to Europe, and with great rapidity.' William H. Wahl, secretary of the Franklin Institute at Philadelphia, writes, 'I believe that, generally, Prof. Wise's proposition, concerning the existence of the elevated easterly current, is correct, and the same view is entertained upon theoretical grounds by metcorologists.' To the same effect writes Prof. Brocklesby, of Trinity College, author of 'Elements of Meteorology', a work recognised as the best elementary text-book on the subject."

Still Prof. Henry is by no means enthusiastically in favour of sceing the dangerous voyage undertaken; he speaks of it as at the best extremely hazardous, and would prefer that some one else in whom he is less interested than he is in Prof. Wise would undertake the risk. His letter to Mr. Wise, in which he thus speaks, is worth quoting for its meteorological value. He says-

"I have no doubt of the fact that, if your balloon can be sustained in the air sufficiently long, a voyage might be made across the Atlantic; but this is the point which, it would appear to mc, from my partial knowledgc of what has been accomplished in the art of ballooning, is yet to be satisfactorily established. No one, however, has had more experience in the art than.yourself, and you ought not to venture on the hazardous yoyage without the fullest assurance that the balloon can be sustained at the requisite elevation for, say, ten days.

"I think it probable that over the ocean at a considerable elevation, the tendency to mect advcrse currents will be less than over the land; on the other hand, however, there will be a chance of mecting a cyclone, which might carry you around a circle of several thousand miles, and throw you back over the coast of the United States, since you would be most likely to meet the northern portion of the great whirl, which would be moving in the western direction, the only possible escape from which would be by ascending to a very high elevation. The higher temperature of the Gulf Stream tends to produce an ascent of air above it during the colder months of the year, but in summer this effect would scarcely be perceptible.

"Your remark in regard to the greater velocity of the easterly motion of the balloon at night is in accordance with meteorological principles, since at this period the unequal heating of the earth by the direct rays of the sun does not take place, and hence adverse currents are not as frequent. The cooling of the atmosphere in that part of the earth which is in the shadow will tend to produce at the surface of the earth, after sunset, a westerly current, while at a certain elcvation above the earth, the current would at the same time be in an opposite direction. In the morning, just before and after sunrise, the current at the surface of the earth, produced by the cooling, would be eastward, while that in the atmosphere above would be westward."

There can be no doubt that this daring expedition, whether it descends without mishap on the shores of Europe, or comes to grief in the middle of the Atlantic, will add something to our knowledge of the atmosphere ; but many will no doubt think that all the knowledge that will be acquired by this sensational and hazardous method might be acquired by safer and more ordinary methods. We certainly, with all our heart, wish the enterprise complete success; but we think it very pertinent to refer to some remarks on the project in $L a$ Nature by the experienced balloonist, MI. G. Tissandier. After referring to the theory of the easterly current in the atmosphere, MI. Tissandier says, "We leave to the aëronaut all the responsibility of this hypothesis, which appears to us to be based upon vague conjectures; we should have a little more confidence in the resources which he expects to find above the Gulf Stream. This warm river, which traverses the extent of the Atlantic, should draw along with it a current of air, which the aërial navigator might take advantage of.

"We do not doubt the good faith of the aëronaut, who has already proved himself to be possessed of boldness and courage, but we believe he has not maturely considered the problem he proposes to solve. To go from New York to England, the aëronaut must travel a space of about 5,500 kilometres. Suppose that exceptional good fortune favours him, that a favourable wind, of mean intensity, having a speed of ten metres per second, blew regularly from west to east, without deviation, he must necessarily sojourn in the atmosphere six or seven days at the least, since the distance traversed in twenty-four hours will be, according to our hypothesis, 864 kilometres. But can an aërostat, no matter how voluminous it may be, constructed under existing conditions, and notwithstanding its complete impcrmeability, remain in the atmosphere for seven days? To this we reply, with the utmost confidence, in the negative. In fact, when a balloon quits the earth, as it rises a part of the enclosed gas is at once expelled by the dilatation due to the diminished pressure of the atmosphere; but the aërostat soon plunges into regions where the temperature is much lower than that of the strata of terrestrial air which it has left. The cold contracts the gas, the balloon loses its ascending power and descends. To maintain it at the level it has reached, it is necessary to diminish the weight, and the aëronaut throws out ballast. If he pass a first night at great altitude, it is certain that he will be thus obliged almost continually to lighten his craft. Next morning, as the sun rises, the bright burning rays heat the gas contained in the aërostat. The balloon, which had partly collapsed during the night, begins to fill out, the loose material stretches like the head of a drum, and it mounts into the higher regions of the atmosphere. It is now that the aêronaut will feel the want of a portion of the ballast he was obliged to cast away during the night. If the sun is hot, the balloon will rise so high that it will be necessary to moderate its ascent by letting off some of the gas. During the second night the reverse process takes place. This time the aerronaut has no longer the same resources as before; the ballast, which is his life, is being continually exhausted. I willingly admit he may have sufficient for the second and even for the third night; but will he have enough for the sixth and seventh night, if the differences of temperature of day and night are considerable, as is probable? The moment will soon come when the sacks of sand will be empty; the balloon will descend without any means being able to hold it back, But instead of encountering a hospitable soil, it strikes against the crest of the waves. The anchor instead of biting, will plunge in vain in the waters; if the wind is violent, in spite of their life-boat, the voyagers may be prepared for a most horrible fate. The aërostat will be piteously raised by the wind, and the terrified train will shoot from wave to wave over the surface of the ocean. Unusually clever will be the men carried along by such a force, if they could manage to find the means of detaching the life-boat."

It is certainly true that it would be very difficult to sustain a balloon at a considerable elevation for six days (if the height of the balloon is a matter of indifference, the guide rope as used by Green would be quite sufficient 
to answer this purpose, even with an ordinary balloon), but we think the management of the balloon may be very well left to Prof. Wise, whose opinion on all practical points of aërostation is probably of more value than that of any other man living. Of all the persons who have devoted themselves professionally to ballooning as a source of income, Prof. Wise is certainly the ablest, and his work on Aëronautics shows him to be possessed of considerable scientific claims. The project could not, thercfore, be in better hands ; and considering the originality and boldness displayed by Prof. Wise in several of his very numerous ascents; there is every reason to believe that nothing will be left undone to bring it to a successful issue. In all the technical matters relating to the balloon, therefore, Prof. Wise may be well trusted to take the best course; and with regard to the meteorological questions involved by consulting not only American meteorologists but also Mir. Glaisher and other gentlemen who have studied the question of the winds in relation to aërostation, it is clear that he intends to leave no stone unturned to obtain the best information attainable, and, at all events, merit success.

\section{MAYNE'S SIDEREAL DIAL}

THIS instrument consists of two moveable circles, which may be made of brass or pasteboard, placed in a common watch-case. The lower and outer one shows the hours doubled up to XXIV., and divided into quarters. The upper one, which is also inner, shows the sixty minutes, 5, 10, \&c. This circle is a narrow one, and works on the plain inmost rim of the lower one, so as to admit of the hours being seen outside the minutes.

Each circle being set to show at the top of the case, where the XII. of the watch comes, the "Sidereal Time at Mean Noon" (given in the Nautical Almanack for each day in the year), the watch is placed in the case, and will continue to show the sidereal time corresponding to mean time approximately for six hours, after which interval the minute circle should $\mathrm{b} z$ put on one minute to ensure greater exactness.

This will be found a near enough approximation for the amateur observer, using an equatorial instrument, and this simple method will be found to save an infinite amount of trouble in finding objects wuhose R.A. is re.

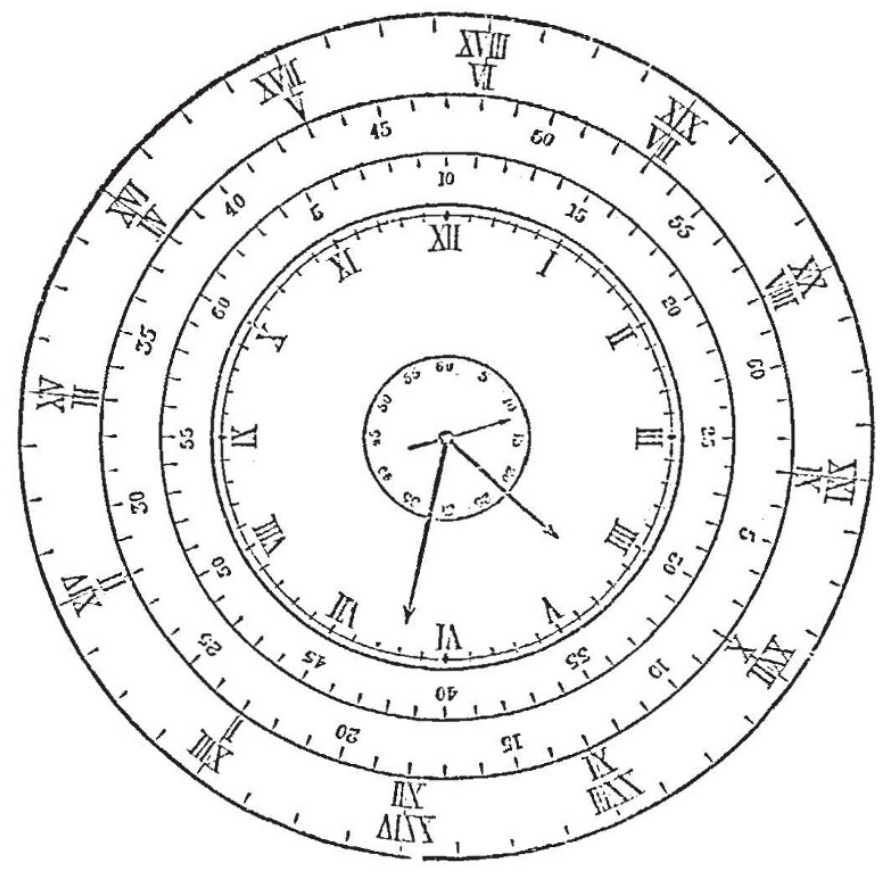

corded in a calalogue, to those who, like the inventor, are unprovided with a sidereal clock.

Mr. Norman Lockyer has suggested as an improvement, the usc of a watch with the seconds' hand in the centre; this would necessitate a third, and still inner circle for the sixty seconds, by which, indeed, subject to an hourly correction of, say ten seconds being tut on, the dial would be rendered accurate enough for rough transit observations; and this circle and seconds hand have been added to the original design in the woodcut, where the dial is set to $\mathrm{V}$. (3) $\left.43_{5}^{3}\right) 47^{\circ} 10$, the Sidereal Time at Mean Noon for the 18 th June, 1873, the hands of the watch representing IV. (1) $32^{*} 12$, which gives the corresponding Sidereal Time X. I9'22 (or applying the last-named correction, say 45 seconds for $4 \frac{1}{2}$ hours), $\mathrm{X}$. $20 \%$.

It is as well perhaps, though scarcely needful, to add (for no one would be likely to make a mistake of 12 hours) that as the dial in the Example also reads XVII. ( $\left.\begin{array}{l}3 \\ 4\end{array}\right) 47^{\circ}$ Io, and as the mean time by the watch may be A.M. or P.M., the observer should bear in mind which half of the 24 hours, both astronomical and mean, he is working in.

The third or seconts circle is not indispensable, as the seconds hand, even in the ordinary position, can be made to fulfil its object, by setting. it at noon to the Sidereal Second on the meridian; thus, in the Example, it would be set to ro, instead of to Zero, when the dial is set at noon, the correction for the equivalent of the lapsed in. terval being applied subsequently as required. But this involves altering the watch, which is objectionable; the use of the third, or seconts circle, is therefore recommended, for although the seconds' hand, as placed in most watches, would not actually point to the Sidereal second, it is easy to refer the position of the mean second to the corresponding part of the watch's face, where the third circle can be read off at once.

\section{Ashton Mayne, Captain,} Bombay Staff Corps, Care of Messrs. Henry S. King \& Co., 65 , Cornhill, London, E.C. 